\title{
Akibat Hukum Jual Beli Hak Atas Tanah Yang Belum Bersertipikat di Kantor Pertanahan Kabupaten Buleleng
}

\section{Thomas Alexander Birehina ${ }^{1}$}

${ }^{1}$ Program Studi Magister (S2) Kenotariatan Fakultas Hukum Universitas Udayana, E-mail: Thomas.alexanderbire@gmail.com

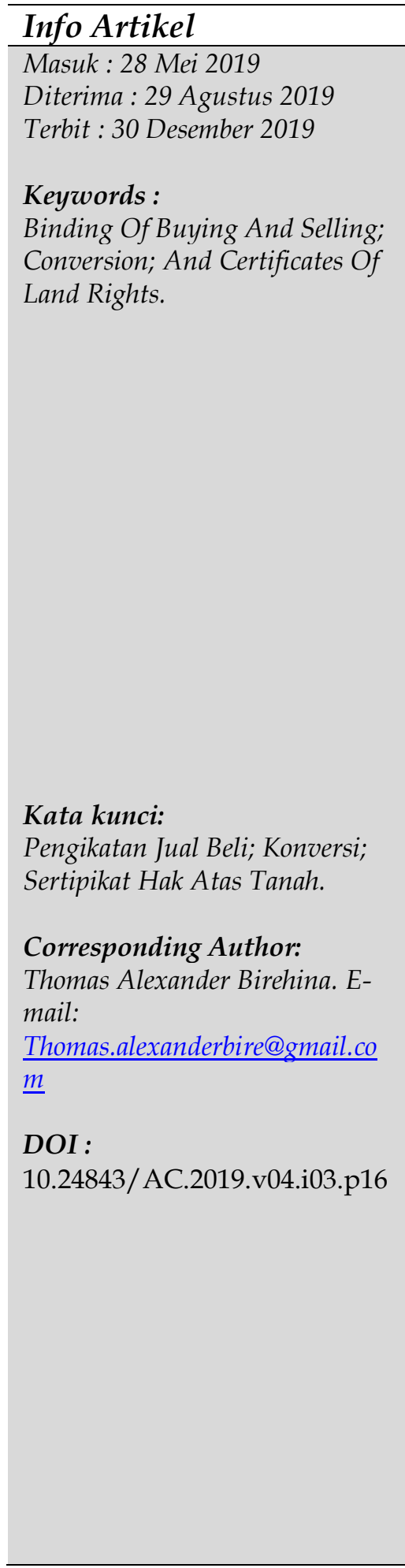

\begin{abstract}
Transfer of land ownership through buying and selling is done by surrendering his land as an object in the form of a certificate. This certificate is used as evidence that states the owner of the rights to his land that will be traded to the buyer. In practice, there is still land for sale in the field that does not yet have a certificate. The purpose of this research is to find out how the procedure of buying and selling land rights that have not been certified as well as the legal consequences of buying and selling land rights that are not yet certified. Empirical juridical research is a type of research in this paper. From the results of the study, the procedure that must be carried out first is by making a purchase agreement before a Notary to secure the interests of both parties, then the land is registered through a conversion at the Land Office for certificate issuance, so that the sale and purchase can be processed before the PPAT to be able to registered at the Land Office so that it is processed behind the name on behalf of the buyer. The legal consequences if the sale and purchase of land that has not been certified is not legal according to the law, unless first done through conversion at the Land Office and preceded by the making of the purchase agreement before the Notary. So that the seller's rights shift to the buyer.
\end{abstract}




\section{Pendahuluan}

Penguasaan terhadap tanah ini bisa beralih dan juga bisa dialihkan kepemilikkannya sesuai dengan yang disebutkan dalam Pasal 20 ayat (2) UUPA. Adanya perpindahan hak oleh karena terjadinya peristiwa hukum itu disebut beralih, contohnya pewarisan. Dialihkan artinya adanya perpind ahan Hak Milik kepada pihaknya yang lain oleh karena terjadinya perbuatan hukum. Salah satu contohnya yakni jual beli. ${ }^{1}$ Tanah yang akan dialihkan melalui jual beli haruslah mendaftarkan perbuatan hukum tersebut ke Kantor Pertanahan agar dapat dicatatkan ke dalam buku tanah, namun sebelumnya sesuai dengan Peraturan Pemerintah yang selanjutnya disebut (PP) Nomer 24 Tahun 1997, pada Pasal 37 ayat (1) haruslah dibuktikan terlebih dahulu oleh akta sebagai bukti adanya transaksi jual beli yang dibuat dihadapan PPAT.

Akta ini biasa disebut dengan akta jual beli yang dibuat oleh Pejabat Pembuat Akta Tanah (PPAT) adalah sebuah alat pembuktiannya yang otentik untuk menyatakan sudah berlangsungnya pengalihan kepemilikan tanah melalui jual beli antara keduabelah pihak yaitu penjual dan pembeli. ${ }^{2}$ Hal ini dikarenakan dibutuhkannya campur tangan pejabat yang berwenang untuk menyelesaikan transaksi jual beli tersebut agar sah dihadapan hukum oleh karena jual beli harus sesuai dengan prosedur yang sudah diatur oleh Undang-Undang yang berlaku. ${ }^{3}$ Namun sebelum dibuatkan akta, haruslah terlebih dahulu pihak penjual menunjukkan sertipikat sebagai bukti pemilik yang kuat dari hak atas tanahnya tersebut. ${ }^{4}$ Dengan begitu PPAT bisa melakukan proses pembuatan akta sebagai bukti untuk dapat didaftarkan di Kantor Pertanahan agar dicatatkan dan sertipikat kepemilikan atas nama penjual tersebut dapat balik nama menjadi kepemilikan dengan nama dari pembeli. ${ }^{5}$

Jual beli di bidang pertanahan yang sudah bersertipikat pada dasarnya tidak mengalami permasalahan dalam pelaksanaannya. Hal ini disebabkan karena baik pemilik status tanah, letak dan luas tanah serta batas-batasnya sudah secara lengkap tertera dalam sertipikat itu. Bagi tanah yang belum mempunyai sertipikat, membutuhkan proses yang cukup panjang dikarenakan si pemilik hak terhadap tanahnya tersebut yang ingin mengalihkan hak miliknya melalui jual beli harus mempunyai sertipikat hak milik untuk pembuktian yang menyatakan bahwa benar tanahnya tersebut atas nama pemiliknya. Berlandaskan dari paparan permasalahan tersebut, perlunya diteliti kembali yang diberi judul "akibat hukum jual beli hak atas tanah yang belum bersertipikat di Kantor Pertanahan Kabupaten Buleleng". Dari fenomena yang sudah dijabarkan diatas, dengan demikian dapat dirumuskan sebuah permasalahan seperti bagaimana prosedur jual beli hak atas tanah yang belum bersertipikat? Dan apa akibat hukum terhadap jual beli hak atas tanah yang belum bersertipikat? Tujuan adanya penulisan dalam penelitian ini yaitu dengan harapan mampu mengembangkan disiplin ilmu hukum, terkhususnya pada bagian disiplin

\footnotetext{
1 Urip Santoso, 2005, Hukum Agraria Dan Hak-Hak Atas Tanah, Kencana, Jakarta, hlm 91.

2 Nurlaila, Ilyas Ismail, Mahdi Syahbandir, 2018, Kepemilikan Tanah Hak Milik Yang Dikuasai Bersama Warga Negara Indonesia (WNI) Dan Warga Negara Asing (WNA) Yang Diperoleh Berdasarkan Warisan Di Provinsi Aceh, Law Journal, Vol II, No 2, hlm 260

${ }^{3}$ Baiq Henni Paramita Rosandi, 2016, Akibat Hukum Jual Beli Hak Atas Tanah Yang Belum Didaftarkan, Jurnal Kajian Hukum Dan Keadilan, Vol IV, No 3, hlm 427

${ }^{4}$ Monica Hapsari, 2018, Pelaksanaan Pendaftaran Tanah Untuk Pertama Kali Secara Sporadik Pada Tanah Yang Belum Bersertifikat Di Kantor Pertanahan Kabupaten Karanganyar, Publikasi Ilmiah, hlm 6

5 Medianotaris, 2015, Jual Beli Menurut Alwesius Ola Berita, URL:http://www.medianotaris.com/ di akses tanggal 21 april 2019
} 
ilmunya kenotariatan mengenai prosedur serta akibat hukum terhadap jual beli hak atas tanah yang belum bersertipikat.

\section{Metode Penelitian}

Penelitian yuridis empiris menjadi jenis penelitian dalam penulisan ini, oleh karena terjadinya kesenjangan antara PP No. 24 Tahun 1997 Tentang Pendaftaran Tanah dengan prosedur jual belinya hak atas tanah yang belum bersertipikat. Penulisan ini mempunyai sumber data untuk diteliti sebagai sumber data utama yang bersumber dari informan dan responden yang terkait melalui proses wawancara dilapangan, sumber data ini biasa disebut sumber data primer. Dan data sekundernya didapatkan dari perpustakaan yang kaitannya dengan obyek daripada suatu penelitian berupa buku-buku, literatur dan dokumen-dokumennya yang resmi termasuk perturan perundang-undangan untuk sebagai bahan kajian pembahasan dalam penelitian ini. ${ }^{6}$ Penelitiannya ini dilakukan di Kantor Pertanahan Kabupaten Buleleng di Singaraja.

Penelitian ini dalam menentukan samplenya menggunakan teknik purposive sampling yaitu dengan cara menentukan responden dan informan sendiri untuk mengumpulkan beberapa keterangan-keterangan beserta beberapa kesaksian yang menunjang dalam menjawab permasalahan pada penelitian ini. Responden dan informan yang dipilih sendiri ini sudah dianggap memilki kriteria dan karakternya yang representatif dalam mewakili sample pada penelitian ini. ${ }^{7}$ Cara dalam menganalisa data pada penulisan ini adalah dengan cara berupa menganalisis data kualitatifnya yang menjadi pokok penting dalam mengelompokkan dan diuraikannya data tersebut pada sebuah pola, dikategorikan dan dengan demikian ditemukannya jawaban dalam penelitian tersebut. ${ }^{8}$ Data tersebut akan diolah dengan alur yang pertama yaitu mengumpulkan data yang akan disusun dengan sistematis kemudian akan direduksi serta diberikan pemaparan dengan demikian didapatnya suatu simpulan yang akan menjawab permasalahan tersebut. ${ }^{9}$

\section{Hasil dan Pembahasan}

\subsection{Prosedur jual beli hak atas tanah yang belum bersertipikat}

Kepemilikan terhadap tanahnya yang dijualbelikan adalah bagian dari upaya memindahkan hak kepemilikan terhadap tanah tersebut. Pada dasarnya jual beli yang dimaksud sebenarnya bukan tanah yang diperjualbelikan itu, melainkan hak terhadap tanah tersebut, atau dalam sisi lainnya obyek jual beli tanah ialah hak terhadap tanah. Proses dijualbelikan hak atas tanah yang belum bersertipikat pada prakteknya di Kabupaten Buleleng baru bisa dilakukan apabila tanah tersebut bersertipikat. Menurut penelitian pada PPAT di Kabupaten Buleleng, ternyata yang paling banyak tanah yang diperjualbelikan adalah tanah hak milik yang sudah bersertipikat. Oleh karena itu pihak penjual yang akan mengalihkan hak terhadap tanahnya yang belum mempunyai sertipikat, haruslah dibuatkan sertipikat lebih dulu dengan melewati tahapan-tahapan atau proses penerbitan sertipikat tersebut untuk bukti kepemilikan hak atas tanah di Kantor Pertanahan. Menurut Notaris/PPAT Lazarus Birehina transaksi jual beli terhadap tanahnya yang belum ada sertipikat antara penjual atau pemilik tanah dan

\footnotetext{
${ }^{6}$ Moleong. Lexy J, 1994, Metodelogi Penelitian Kualitatif, Remaja Rosda Karya, Bandung, hlm 35

${ }^{7}$ Mustofa Burhan, 2004, Metode Penelitian Hukum, Rineka Cipta, Jakarta, hlm 91.

8 Moleong. L, 1999, Metode Penelitian Kualitatif, PT Remaja Rosda Karya, Bandung, hlm 103

${ }^{9}$ Soerjono Soekanto, 1986, Pengantar Penelitian Hukum, UI Press, Jakarta, hlm 250
} 
pembeli harus telah mencapai kesepakatan terlebih dahulu mengenai tanahnya, harga tanah dan waktu jual beli yang akan dilakukan. Biasanya setelah ada kesepakatan antara penjual dan calon pembeli, untuk mengikat keduabelah pihak terlebih dahulu dibuatkan perikatan jual beli di hadapan Notaris.

Keduabelah pihak perlu membuat perikatan jual beli untuk mengamankan kepentingan mereka yang dibuat dalam bentuk akta sebagai perjanjian permulaan yang menyatakan adanya perbuatan dari pihak pertama yang menjual kepada pihak kedua yang membeli namun obyek yang diperjualbelikan tersebut masih harus melalui tahapan/proses sebelum dipindahtangankan dari pihak penjualnya kepada pihak pembeli. Ini disebabkan belum adanya sertipikat sebagai alat pembuktian kepemilikan dari obyek tanahnya yang akan diperjualbelikan, oleh karena itu agar tranksaksi jual belinya itu tetap berlangsung antara pihak penjual dengan pihak pembeli dibutuhkan tanda kesepakatan untuk menghindari terjadinya ingkar janji oleh keduabelah pihak dan selain itu dapat memberikan rasa aman bagi kepentingan para pihak maka dibuatkan perikatan jual beli dihadapan Notaris sebagai tanda bukti kesepakatan yang otentik. ${ }^{10}$

Perikatan jual beli tersebut yang dibuat dihadapan notaris untuk mengikat para pihak agar tetap sepakat melakukan tranksaksi jual beli walaupun tanah sebagai obyek yang diperjualbelikan masih dalam proses penerbitan sertipikat hak milik di Kantor Pertanahan. Adanya perikatan jual beli ini dapat digunakan untuk modal dasar dalam menjalani tahapan-tahapan atau proses penerbitan sertipikat tersebut. Proses penerbitan sertipikat tanah yang sebelumnya tanah tersebut belum didaftarkan pada buku tanah maka harus melewati proses pendaftaran tanah pertama kalinya atau biasa disebut konversi. Konversi atau pendaftaran tanah pertama kalinya ini pada pelaksanaanya di Kantor Pertanahan Kabupaten Buleleng diawali dengan melengkapi segala persyaratan-persyaratan seperti: surat permohonan penegasan konversi, surat permohonan kepada kepala kantor pertanahan, kutipan buku letter C desa, surat keterangan riwayat tanah, keterangan tidak dalam sengketa, surat pernyataan telah memasang tanda batas. Persyaratan-persyaratan ini terdapat dalam blanko permohonan konversi di Kantor Pertanahan. Blanko permohonan ini didalamnya terdapat beberapa formulir yang harus diisi dan dilengkapi sebagaimana persyaratan yang disebutkan diatas oleh pemohon.

Menurut Bapak Putu Widarma bagian Kepala sub seksi Pendaftaran Hak mengatakan dalam surat permohonan ini pemohon juga harus melampirkan kartu tanda penduduk (KTP) beserta foto copynya sebagai identitas diri dan Petuk Pajak Bumi atau girik sebagai identitas dari tanah tersebut atau foto copy letter $C$ dari kepala desa yang sudah dilegalisir sesuai dengan aslinya dan SPPT PBB (Surat Pemberitahuan Pajak Terutang Pajak Bumi Bangunan) tahun berjalan serta melampirkan lampiran-lampiran yang telah dijelaskan diatas. SPPT PBB bisa didapatkan di kantor kelurahan sesuai dengan lokasi obyek pajak berada yang berisi nama dan dari wajib pajak tersebut. Penerima wajib pajak mendapatkan SPPT PBB yang diberikan oleh masing-masing kelian adat atau kepala dusun dari kelurahan yang diterbitkan oleh dinas perpajakan. Pemerintah mengeluarkan SPPT PBB berdasarkan buku letter C sesuai dengan kedudukan dari objek pajak berada yang tercatat di kantor kelurahan ataupun kantor desa. ${ }^{11}$

${ }^{10}$ Hasil wawancara dengan Lazarus Birehina, Notaris/PPAT Tanggal 25 April 2019

${ }^{11}$ Hasil wawancara dengan Putu Widarma kepala sub seksi Pendaftaran Hak di Kantor Pertanahan Kabupaten Buleleng Tanggal 24 April 2019. 
Berkas permohonan yang telah diterima dan diperiksa serta lengkap, maka berkas dientri untuk cetak surat perintah setor untuk agar dapat melakukan pembayaran seluruh pembiayaan yang sudah ditentukan oleh Badan Pertanahan Nasional di loket keuangan. Setelah melakukan pembayaran tersebut pemohon akan mendapatkan tanda terima telah melakukan pembayaran sebagai bukti untuk pemohon dapat menunggu diterbitkannya sertipikat hak milik tanah. Proses penerbitannya sertipikat kurang lebih selama 60 hari terhitung dari setelah proses permohonan hingga pengukuran pada objek tanah tersebut selesai dan hasilnya dibawa ke Kantor Pertanahan. ${ }^{12}$ Prosedur pendaftaran tanah selanjutnya terus dilakukan oleh kantor pertanahan selagi pemohon menunggu terbitnya sertipikat tanahnya. Prosesnya tersebut yaitu melakukan pengelolaan dan penelitian data yuridis oleh kantor pertanahan. Kantor Pertanahan melakukan pengelolaan seluruh dokumen yang sudah diserahkan oleh pemohon yang kemudian dari pihak Kantor Pertanahan mengecek kelengkapan dokumen tersebut dan setelah itu penelitian lapangan dilakukan di lokasi obyek tanah itu berada oleh pihak Kantor Pertanahan.

Penelitian lapangan yang dilaksanakan dari pihak kantor pertanahan yaitu menetapkan batas-batas bidang tanah dengan mengukur luasnya bidang tanah tersebut dan membuatkan surat ukurnya. Batas-batas pembidangan tanah yang telah diukur tersebut kemudian dipetakan kedalam peta dasar pendaftaran. Tanda-tanda batasnya yang telah ditentukan ditarik dari sudut-sudut bidang tanah tersebut, menentukan pemetaan bidang tanah yang akan diukur. Dengan demikian pihak kantor pertanahan akan mendapatkan data yang digunakan dalam proses pendaftaran tanah. Data yang sudah dikumpulkan tersebut akan dilanjutkan oleh Panitia Adjukasi (Panitia A) dengan mengidentifikasi bukti dari kepemilikan atau penguasaan tanah tersebut yang kemudian akan ditarik simpulan oleh Panitia A melalui Kepala Seksi dan Pendaftaran Tanah mengenai kenyataannya menguasai dan menggunakan tanah tersebut. Kepala Seksi akan mengumumkan mengenai bidang tanahnya berdasarkan dari kesimpulan data yang telah diidentifikasi. Pengumuman bidang tanah tersebut dilakukan selama enam puluh (60) hari lamanya di Kantor Pertanahan dan Kantor Desa di tempat kedudukan obyek tanah itu berada. Dengan demikian selama enam puluh hari lamanya tidak ada penolakan, maka dari Kantor Pertanahan dapat menerbitkan sertipikat tersebut. ${ }^{13}$ Waktu yang ditempuh saat melakukan proses pendaftaran tanah yaitu 98 hari terhitung dari awal pemohon melakukan permohonan pendaftaran hingga selesai. ${ }^{14}$ Namun pada prakteknya dilapangan waktu yang ditempuh oleh pemohon dari awal pemohon mendaftar pertama kalinya hingga diterbitkannya sertipikat sebagai hak miliknya pemohon itu bisa sampai 6 bulan hingga 1 tahun menyesuaikan dengan keadaan dilapangan. ${ }^{15}$

Terbitnya sertipikat tanah berupa hak milik ini sebagai bukti untuk dapat dilanjutkan pada tahapan berikutnya yaitu jual belinya tanah tersebut. Bukti mengenai kepemilikan berupa sertipikat tanah ini akan memudahkan proses jual belinya yang dilaksanakan dihadapan PPAT. Tahapan selanjutnya yaitu dibuatkannya akta jual beli dihadapan PPAT dengan melampirkan sertipikat tanah tersebut. Namun sebelum dibuatkan Akta Jual Belinya, PPAT akan melakukan pengecekkan kembali ke Kantor Pertanahan mengenai sertipikat tersebut yang pada penelitian ini di Kantor

\footnotetext{
${ }^{12}$ Hasil wawancara dengan wayan sukarja Pegawai Kantor Pertanahan Kabupaten Buleleng Tanggal 24 April 2019

${ }^{13}$ Hasil wawancara dengan Putu Widarma kepala sub seksi Pendaftaran Hak di Kantor Pertanahan Kabupaten Buleleng Tanggal 24 April 2019.

${ }^{14}$ Berdasarkan kartu kendali untuk permohonan pengakuan

${ }^{15}$ Hasil wawancara dengan Horniah Pegawai Kantor Notaris/PPAT Tanggal 25 April 2019
} 
Pertanahan Kabupaten Buleleng. Selain itu keduabelah pihak baik dari pembeli dan penjual harus melengkapi persyaratan sebagai data formil untuk melakukan prosedur pembuatan akta, dalam hal ini persyaratan sebagai penjual seperti sertipikat tanahnya yang asli, KTP asli suami istri (untuk yang sudah berkeluarga), surat yang menyatakan persetujuan dari suami atau istri (untuk yang sudah berkeluarga), KK (kartu Keluarga) yang masih berlaku, dan Kwitansi PBB (5 tahun terakhir). Sedangkan untuk persyaratan sebagai pembeli seperti KTP dan KK yang masih berlaku. Pembuatan akta tersebut tidak diperbolehkan memuat kata-kata "sesuai atau menurut keterangan para pihak" kecuali didukung oleh data formil. PPAT juga berwenang menolak pembuatan akta yang tidak didasari dengan data formil. ${ }^{16}$

Kewajiban pihak pertama/penjual dalam transaksi jual beli yaitu wajib melakukan pembayaran pajak jual beli. Pembayaran pajak untuk pihak pertama/penjual biasa disebut membayar pajak penghasilan (PPH) di Kantor Pos atau dapat dibayarkan di Bank dengan sebesar 2,5\% dari harga jual tanahnya keseluruhan. Sedangkan kewajiban dari pihaknya yang kedua/pembeli pada transaksi jual beli yaitu wajib melakukan pembayaran pajak BPHTB (Bea Perolehan Hak Atas Tanah dan Bagunan) sebesar 5\% dengan lebih dulu dikurangi NJOP (Nilai Jual Objek Pajak) Tidak Kena Pajak sesuai perhitungan yang ditentukan Badan Keuangan Daerah di Kabupaten Buleleng sesuai dengan nilai jual dan lokasi tanah tersebut. Selain itu kewajiban pihak pertama/penjual memberikan pernyataan yang ditulis dalam akta yang menyatakan tanahnya yang dijadikan obyek daripada jual beli tersebut tidak berada pada kedudukan sebagai jaminan, digadaikan atau dalam status sengketa. Demikian pula Pihak kedua selaku pembeli juga memberikan pernyataan yang ditulis dalam akta yang menyatakan bahwa pihak kedua tidak mempunyai hak mengambil alih tanah selain yang sudah disepakati keduabelah pihak pada pengikatan jual beli. Selanjutnya setelah PPAT melakukan pengecekan di Kantor Pertanahan dan pihak penjual maupun pihak pembeli sudah melengkapi persyaratannya tersebut, maka PPAT dapat melakukan proses untuk dibuatkan akta jual belinya. ${ }^{17}$

Keduabelah pihak haruslah hadir dalam proses pembuatan akta jual beli ini baik pihak pertama sebagai penjual dan pihak kedua sebagai pembeli. Apabila salah satu dari pihak tidak dapat menghadiri pada proses pembuatan akta tersebut, maka dapat diwakilkan dengan melampirkan surat kuasa yang dituliskan oleh pihak yang tidak hadir. Selain itu pada proses dibuatkannya akta jual beli wajib disaksikan minimal dua orang sebagai saksi yang mutlak penting karena apabila dikemudian hari terjadi sengketa maka kedua saksi ini yang akan menjelaskan kepada hakim bahwa memang benar telah terjadi transaksi jual beli tanah dihadapan PPAT. ${ }^{18}$ Selanjutnya isi dari akta akan dibacakan dan dijelaskan oleh PPAT, serta menjelaskan mengenai proses pembayarannya sesuai dengan kesepakatan bersama. Apabila setelah dibacakan para pihak sepakat dan setuju dengan isi akta tersebut, maka proses selanjutnya keduabelah pihak akan melakukan penandatanganan dalam aktanya yang disaksikan dengan ditandatangani oleh saksi dan PPAT. Keduabelah pihak Penjual dan pembeli disini akan diberikan salinan dari akta jual beli tersebut, sedangkan aktanya yang asli dibuatkan dalam dua rangkap. PPAT akan menyimpan rangkap pertamanya di Kantor dan rangkap yang kedua digunakan untuk didaftarkan ke Kantor Pertanahan dengan segera sebagai bagian dari proses pembalikan nama tersebut. Dengan telah

${ }^{16}$ Herlina Ratna SN, 2015, Kewenangan Pejabat Pembuat Akta Tanah Dalam Perjanjian Jual Beli Tanah, Jurnal Keadilan Progresif, Vol VI, No 2, hlm 99

${ }^{17}$ Hasil wawancara dengan Lazarus Birehina, Notaris/PPAT Tanggal 25 April 2019

${ }_{18}$ Ardiansyah Zulhadji, 2016, Peralihan Hak Atas Tanah Melalui Jual Beli Tanah Menurut Undang Undang Nomor 5 Tahun 1960, Jurnal Hukum, Vol V, No 4, hlm 33 
terdaftarnya akta jual belinya tersebut pada Kantor Pertanahan maka sertipikat tanah atas nama penjual akan dicoret dan digantikan namanya dalam sertipikat tersebut atas namanya pembeli.

\subsection{Akibat hukum terhadap jual beli hak atas tanah yang belum bersertipikat.}

Orang yang melakukan suatu perbuatan hukum sudah pasti akan menghasilkan suatu akibat yang biasa disebut akibat hukum. Prosedur jual beli hak atas tanahnya yang belum mempunyai sertipikat memiliki akibat hukum yang ditimbulkan berdasarkan Pasal 37 ayat (1) PP No. 24 Tahun 1997 yang menegaskan agar dapat terdaftar dalam mengalihkan tanah melalui perbuatan jual beli ini haruslah dibuktikan terlebih dulu oleh akta yang dibuat dihadapan PPAT. Jadi sebagai bukti yang otentik terhadap tranksaksi jual beli tanahnya untuk dapat terdaftar haruslah melalui aktanya PPAT. Tanpa adanya pembuktian dari akta PPAT mengenai tanahnya yang diperjual belikan berdasarkan kehendak dari keduabelah pihak, maka transaksi tersebut belum dapat diproses oleh Kantor Pertanahan dan akibatnya tidak dapat memperoleh pembuktian kepemilikan hak yang kuat dalam bentuk sertipikat tanah.

Pasal 1457 KUHPerdata memberikan pengertian jual beli adalah suatu persetujuan dengan mana pihak yang satu mengikatkan dirinya untuk menyerahkan suatu kebendaan, dan pihak yang lain untuk membayar harga yang telah diperjanjikan. Maka demikian bisa ditafsirkan jual beli tersebut merupakan kegiatan perjanjian yang akan menimbulkan ikatan pada keduabelah pihak dengan tujuan memberi suatu benda sehingga akan menimbulkan kewajiban dari para pihak, yang mana pihak pertama selaku penjual memberikan sesuatu atau benda yang dijual kepada pihak kedua selaku pembeli dan pihak kedua memberi uang untuk mendapatkan benda yang dijual tersebut kepada pihak pertama. Disisi lain Pasal 1458 KUHPerdata menyebutkan transaksi jual beli yang dilakukan oleh keduabelah pihak sudah dapat dikatakan terjadi ketika adanya kesepakatan dari keduabelah pihak untuk benda atau sesuatu yang menjadi objek jual beli beserta harga yang akan dibayarkan meskipun belum adanya penyerahan dan pembayaran harga dari benda tersebut. ${ }^{19}$

Perjanjian jual beli tanah merupakan suatu perjanjian dimana para pihak mengikatkan diri untuk melakukan perbuatan hukum jual beli dimana tanah menjadi obyeknya, perjanjian jual beli tanah harus memenuhi syarat materiil serta syarat formil, dimana syarat materiil menentukan akan sahnya suatu perjanjian jual beli tanah tersebut, setelah persyaratan materiil terpenuhi, maka jual beli tanah tersebut dilakukan pembuatan akta jual beli atas tanah yang dibuat dan ditandatangani dihadapan PPAT yang juga hal tersebut merupakan syarat formil. ${ }^{20}$

Menurut Notaris/PPAT Lazarus Birehina tranksaksi jual beli yang dlilakukan oleh keduabelah pihak tetapi pembayaran harga tanahnya belum dibayar lunas oleh pembeli kapada penjual, maka untuk memperkuat kedudukan pembeli, akan dibuatkan suatu perikatan jual beli. Perikatan jual beli dibuat untuk menyatakan telah terjadinya perbuatan hukum mengalihkan kepemilikan terhadap tanah yang belum mempunyai sertipikat untuk mengikatnya keduabelah pihak antara pihak pertama/sebagai penjual dengan pihak kedua/sebagai pembeli. Perikatan jual beli ini berisi hak dan kewajiban keduabelah pihak, yangmana pihak kedua sebagai pembeli

${ }^{19}$ Adrian Sutedi, 2007, Peralihan Hak Atas Tanah Dan Pendaftarannya, Sinar Grafika, Jakarta, hlm 84.

${ }^{20}$ Ermasyanti, 2012, Kewenangan Pejabat Pembuat Akta Tanah Dalam Proses Jual Beli Tanah, Jurnal Keadilan Progresif, Vol III, No 1, hlm 79 
agar membayar sejumlah uang dan pihak yang pertama sebagai penjual berhak menerima sejumlah uang, begitu pun sebaliknya yang berkedudukan sebagai pihak penjual wajib menyerahkan haknya terhadap tanah yang dimiliki dan yang berkedudukan sebagai pihak pembeli berhak menerima hak terhadap tanahnya yang sudah dijadikan obyek jual beli oleh pihak pertama. Dengan demikian perikatan jual beli ini mempunyai beberapa persyaratan untuk menentukan sahnya jual beli hak terhadap tanahnya tersebut dengan memperhatikan beberapa persyaratan yang sudah diatur pada Pasal 1320 KUHPerdata untuk menentukan perjanjian tersebut sah atau tidak. ${ }^{21}$

PPAT harus memperhatikan Pasal 1320 KUHPerdata untuk menghindari kecacatan hukum pada aktanya sehingga dapat mengakibatkannya akta batal demi hukum atau dapat dibatalkan. Bila persyaratan-persyaratan tersebut sudah dipenuhi, maka dapat dilakukan proses selanjutnya yaitu dibuatkannya akta jual beli dihadapan PPAT. Akta ini sebagai alat bukti mengenai pengalihan kepemilikkan tanah yang sudah dialihkan ke pihak pembeli, namun hal ini belum dapat menjadi pembuktian untuk pihak ketiga, oleh karena pihak ketiga barulah dapat mengetahui peralihan tersebut berdasarkan nama kepemilikan dan semua hal yang tertulis dalam buku tanah serta dalam sertipikat tanahnya tersebut. Oleh karena itu secara yuridis pembeli yang melakukan tranksasi jual beli belum jadi pemilik hingga kedudukannya sah dalam segi pembuktian menjadi pemilik apabila telah dilakukan pendaftaran pengalihan hak terhadap tanahnya tersebut di Kantor Pertanahan. Akibat hukum dari jual beli yang telah terdaftar ini adalah terdapatnya perubahan terhadap data yuridis. ${ }^{22}$

Berdasarkan dari analisis tersebut, tanah yang diperjualbelikan namun belum memiliki sertipikat belum sah menurut hukum, kecuali telah melakukan prosedur berdasarkan persyaratan-persyaratan yang telah dijelaskan diatas dengan bersandar pada peraturan perundang-undagan yang berlaku. Maka dari itu prosedur tersebut dapat dilakukan dengan menimbulkan akibat hukum bagi 3 (tiga) pihak, diantaranya adalah:

\section{Bagi penjual}

Bahwa penjual melepas hak atas tanahnya yang dimiliki namun sebelumnya terhadap tanahnya yang belum bersertipikat harus terdaftar melalui konversi terlebih dulu di Kantor Pertanahan agar mendapatkan sertipikat Hak milik, barulah kemudian hak milik dari penjualnya dialihkan kepada pembeli, dan haknya penjual menjadi hapus.

\section{Bagi pembeli}

Bahwa pembeli mendapat hak baru dan berlaku sebagai pemilik hak terhadap tanah yang dijualbelikan. Begitu juga penguasaannya dari tanah tersebut, apabila penyerahan obyek jual beli yaitu berupa tanah telah dilengkapi dokumen-dokumen hukumnya yang diisyaratkan sudah benar mengenai subyek dan obyeknya serta harga yang dibayarkannya kepada penjual telah lunas maka hak atas tanah telah menjadi kekuasaan dari si pemegang hak baru atau pembeli.

\section{Bagi Kantor Pertanahan}

Kantor Pertanahan bertugas untuk mendaftarkan haknya melalui konversi tanah yang belum bersertipikat yang diminta oleh penjual sehingga menjadi hak milik penjual dan juga bertugas untuk mencatatkan peralihan haknya terhadap tanah tersebut, dengan mengganti register penjual kepada register pembeli, yang semulanya masih menjadi

\footnotetext{
${ }^{21}$ Hasil wawancara dengan Lazarus Birehina, Notaris/PPAT Tanggal 25 April 2019

22 Ibid
} 
milik penjual, setelah terjadinya proses jual beli maka hak miliknya beralih menjadi milik pembeli.

\section{Kesimpulan}

Prosedur yang harus dilakukan terlebih dahulu adalah dengan pembuatan perikatan jual beli dihadapan Notaris, kemudian tanahnya yang belum bersertipikat di daftarkan dengan dikonversikan di Kantor Pertanahan untuk diterbitkan sertipikat, setelah diterbitkannya sertipikat barulah dapat diproses akta jual belinya yang dibuat dihadapan PPAT, kemudian akta tersebut didaftarkan di Kantor Pertanahan agar diproses balik nama atas nama pembeli. Akibat hukum bilamana tranksaksi jual beli tanah yang belum bersertipikat tersebut dilakukan belum sah menurut hukum, kecuali dapat dilakukan terlebih dahulu melalui konversi di Kantor Pertanahan dan didahului pembuatan perikatan jual beli untuk mengikat kedua belah pihak dihadapan Notaris. Dengan demikian barulah hak kepemilikan atas tanah tersebut dapat beralih dari penjual kepada pembeli. Untuk itu disarankan, para pemilik tanah yang belum mempunyai Sertipikat Hak Milik mendaftarkan tanahnya di Kantor Pertanahan sebelum berniat menjual agar proses jual beli yang dilakukan dihadapan PPAT lebih cepat dan mudah. Maka dari itu, Kantor Pertanahan hendaknya mempermudah proses pendaftaran tanah untuk menerbitkan sertipikat hak atas tanah dengan persyaratanpersyaratan yang mampu dijangkau para pemilik hak atas tanah.

\section{Daftar Pustaka}

\section{Buku}

Adrian Sutedi, 2007, Peralihan Hak Atas Tanah Dan Pendaftarannya, Sinar Grafika, Jakarta.

Effendi Perangin, 1991, Hukum Agraria Di Indonesia Suatu Telaah Dari Sudut Pandang Praktisi Hukum, Rajawali Press, Jakarta.

Moleong, Lexy J, 1994, Metodelogi Penelitian Kualitatif, Remaja Rosda Karya, Bandung. 1999, Metode Penelitian Kualitatif, PT Remaja Rosda Karya, Bandung.

Mustofa Burhan, 2004, Metode Penelitian Hukum, Rineka Cipta, Jakarta.

Urip Santoso, 2005, Hukum Agraria Dan Hak-Hak Atas Tanah, Kencana, Jakarta.

\section{Jurnal}

Ardiansyah Zulhadji, 2016, Peralihan Hak Atas Tanah Melalui Jual Beli Tanah Menurut Undang Undang Nomor 5 Tahun 1960, Jurnal Hukum, Vol V, No 4

Baiq Henni Paramita Rosandi, 2016, Akibat Hukum Jual Beli Hak Atas Tanah Yang Belum Didaftarkan, Jurnal Kajian Hukum Dan Keadilan, Vol IV, No 3

Ermasyanti, 2012, Kewenangan Pejabat Pembuat Akta Tanah Dalam Proses Jual Beli Tanah, Jurnal Keadilan Progresif, Vol III, No 1

Herlina Ratna SN, 2015, Kewenangan Pejabat Pembuat Akta Tanah Dalam Perjanjian Jual Beli Tanah, Jurnal Keadilan Progresif, Vol VI, No 2

Monica Hapsari, 2018, Pelaksanaan Pendaftaran Tanah Untuk Pertama Kali Secara Sporadik Pada Tanah Yang Belum Bersertifikat Di Kantor Pertanahan Kabupaten Karanganyar, Publikasi Ilmiah

Nurlaila, Ilyas Ismail, Mahdi Syahbandir, 2018, Kepemilikan Tanah Hak Milik Yang Dikuasai Bersama Warga Negara Indonesia (WNI) Dan Warga Negara Asing (WNA) Yang Diperoleh Berdasarkan Warisan Di Provinsi Aceh, Law Journal, Vol II, No 2 


\section{Peraturan Perundang-undangan}

Kitab Undang-Undang Hukum Perdata

Peraturan Kepala Badan Pertanahan Nasional Nomor 6 Tahun 1989 Tentang Penyempurnaan Bentuk Akta Pejabat Pembuat Akta Tanah

Peraturan Pemerintah No. 24 Tahun 1997 Tentang Pendaftaran Tanah

Peraturan Pemerintah No. 37 Tahun 1998 Tentang Peraturan Jabatan Pejabat Pembuat Akta Tanah

Undang-Undang Dasar Republik Indonesia 1945

Undang-Undang No. 5 Tahun 1960 Tentang Peraturan Dasar Pokok-Pokok Agraria.

Internet

Medianotaris, 2015, Jual Beli Menurut Alwesius Ola Berita, URL:http://www.medianotaris.com/ di akses tanggal 21 april 2019 